\title{
THE ORIGIN AND FIRST TEST OF PUBLIC CALLINGS*
}

Frequently in defining rules of law we must delve deeply into the past to find the reason for the rule of conduct or liability. The reason in many cases has ceased to exist, yet the rule still lives; the dead fabric interwoven with the newer fine-spun creations of this age. A field of law that is enclosing within itself vast portions of old law, at an unusually rapid rate today, is that which concerns businesses affected with a public interest. The exact direction which this development shall take, accelerated by the immense pressure brought by our industrial structures of this day, is open to wide and interesting speculation. Whether it will eventually include all businesses within its grip, like a giant octopus pressing its unwelcome hold, silently and unconsciously upon one class of business at a time, or whether it shall soon be caught and held within bounds by definite rules soundly worked out, is worth considering. We have the view presented of a bureaucratic government regulating every phase of human activity. Whether our government is progressing or retrogressing at this time, we should know. Are we reverting to the paternalism of the thirteenth century, or the laissez faire policy and extreme individualism of the seventeenth and eighteenth centuries? Or is it a middle course we are steering? Practical reasons may be found for an investigation of the original duties and their limitations upon business.

I.

The Duty to Use Care.

Early cases indicate that certain duties were imposed upon those in a trade, or common calling, to care for property, while like duties were not imposed upon others on the same state of facts. James Barr Ames points out: ${ }^{1}$

"The original notion of a tort to one's person or property was an injury caused by an act of a stranger. ... If one saw fit to authorize another to come into contact with

*The writer wishes to acknowledge his indebtedness to Professor Hugh E. Willis, of Indiana University, for reading the manuscript and offering many helpful suggestions.

${ }^{2} 3$ Select Essays in Anglo-American Legal History 261 
his person or property, and damage ensued, there was, without more, no tort. The person injured took the risk of all injurious consequences, unless the other expressly assumed the risk himself, or unless the peculiar nature of one's calling, as in the case of the smith, imposed a customary duty to act with reasonable skill. This conception is well shown by the remarks of the judges in a case against a horse doctor. ${ }^{2}$

"Newton, C. J.: 'Perhaps he applied his medicine de son bon gré, and afterwards your horse died; now, since he did it de son bon gré you shall not have an action. . . . Paston, J.: 'You have not shown that he is a common surgeon to cure such horses, and so, although he killed your horse by his medicines, you shall have no action against him without an assumpsit."

This general duty to use care is noted by Fitzherbert in $\mathrm{I}_{5} \mathrm{I} 4$, who said:

"If a smith prick my horse with a nail, I shall have my action on the case against him without any warranty by the smith to do it well; for it is the duty of every artificer to exercise his art rightly and truly as he ought."

One of the earliest cases in the books was against an innkeeper. It was alleged that the plaintiff's goods were stolen while in the custody of the innkeeper and he was chargeable by the custom of the realm. No fault was alleged and it was demurred to.

Knevet, J., said it was like the case of a suit against the hundred by one robbed within it. ${ }^{4}$

In the Doctor and the Student ( $\mathrm{I}_{5} \mathrm{I} 8$ ), it is said:

"It is commonly holden in the laws of England if a common carrier go by the ways that be dangerous for robbing, or drive by night or in other inconvenient time and be robbed; or if he overcharge a horse whereby he falleth into the water, or otherwise so that the stuff is hurt or impaired; that he shall stand charged for his misdemeanor; and if he would percase refuse to carry it unless promise were made unto him that he shall not be charged for no misdemeanor that should be in him, the promise were void;

${ }^{2}$ Y. B. 19 H. vi, f. 49 , pl. 5 (1440).

${ }^{3}$ Nat. BREv. $94 \mathrm{~d}$.

'Y. B. 42 ED. III, f. II, pl. I3 (1368). 
for it were against reason and against good manners, and so in all other cases, like. And all these diversities be granted by secondary conclusions derived upon the law of reason, without any statute made in that behalf. And peradventure laws, and conclusions therein be the more plain, and the more open. For if any statute were made therein I think verily more doubts and questions would arise upon the statute than doth now when they be only argued and judged after the common law." 5

The records from 1367 to 1518 show a well recognized liability of those engaged in a trade, because of the custom of the realm or public policy. In no case is mention made of an undertaking or assumpsit. This view is taken by Mr. Justice Holmes:

"If damage had been done or occasioned by the act or omission of the defendant in the pursuits of some of the more common callings, such as that of the farrier, it seems that the action would be maintained, without laying an assumpsit, on the allegation that he was a 'common' farrier. The latter principle was also wholly independent of bailment. It expressed the general obligation of those exercising a public or 'common' business to practise their art on demand, and show skill in it." 8

This rule of liability is brought out still more strongly when we examine the earlier cases of assumpsit. They were all, without exception, against persons exercising a trade or calling. ${ }^{7} \mathrm{Did}$ this duty to use care, imposed upon common callings, owe its origin to the action of assumpsit, or did the law recognize this liability previously? The writer believes the origin of this duty

${ }^{5}$ Dialogue 2, c. 38.

- The Common Law 184

"The earliest cases in which an assumpsit was laid in the declaration were cases against the ferryman, who undertook to carry the plaintiff's horse over the river, but overloaded the boat, whereby the horse was drowned (Y. B. 22 Ass. 94, pl. $4 \mathrm{I}$ ) ; against a surgeon who undertook to cure the plaintiff or his animals but who administered contrary medicine or otherwise unskillfully treated their patients (Y. B. 43 Ed. III, f. 6, pl. II (1369); II R. 2 Fitz. Ab., Action on the case, 37; Y. B. 3 H. vI, f. 36 , pl. 33 (1424) ) against a smith for laming a horse while shoeing it (Y. B. 46 Ed. IIr, f. I9, pl. Ig (I372); Y. B. I2 Ed. IV, f. I3, pl. 9 (I472) against a barber who undertook to shave the beard of the plaintiff with a clean and wholesome razor, but who performed the work negligently and unskillfully to the great injury of the plaintiff's face (I4 H. vII Rast. Ent. 2, b. I (I498)) ; against a carpenter who undertook to build well and faithfully but who built unskillfully (Y. B. II H. IV, f. 33, pl. 60 (I409))." AMEs, op. cit. supra
note $I$ at 260 . 
is not in the action of assumpsit, but rather the reverse; assumpsit, at least to a great extent, owes its origin to the duty of those engaged in common callings to use care. It seems peculiar that assumpsit should apply in the first instances only to active misconduct by those in common callings, and not to every one who should be guilty of such misconduct. The only personal actions available prior to the action on the case ( 1285 ) were: covenant, trespass, account, detinue, replevin, debt, and deceit. Under none of these, according to the early theory of liability, could a duty be imposed upon common callings which differed from that imposed upon every one regardless of calling. When there is no remedial law for enforcement of such duties we could hardly say that such rights or duties existed. Hence the origin of the duty to use care must have been between the date of the action on the case and the time when the action of assumpsit was developed.

There is some ground for the belief that the action of deceit (before the action on the case affected it) gave some sort of a remedy. This action as first used was of a criminal nature. ${ }^{s}$ The damages being paid part to the king, and part to the wronged person. It could be used only when a person had been deceived in a civil action by the act of another person. There is no record of any other instance of its use. ${ }^{9}$

When the action on the case was developed, by analogy, we have an action on the case in the nature of deceit, an action in consimili casu with the old action of deceit. This newer action of deceit was vastly greater in scope than the old action. Ames says: ${ }^{10}$

"A vendor was not answerable to the vendee for any defect of title or quality in the chattels sold unless he had either given an express warranty, or was under a public duty, from the nature of his calling, to sell articles of a certain quality. A taverner, or vintner was bound as such

${ }^{8}$ Fitz. Nat. Brev. 95e et seq.; Reg. Brev. Orig. II2 et seq.

"This form of action, like the others, is ancient, being older, by more than a century, than special assumpsit. The words super se assumpsit were not used, it is true, in a count upon a warranty; but the notion of undertaking was equally well conveyed by warrantizando vendidit." AMEs, op. cit. stupra note I at 266 .

${ }^{10}$ Ibid. at 268. 
to sell wholesome food and drink. ${ }^{11}$ Their position was analogous to that of the smith, common carrier, and innkeeper."

This seems to indicate that there was a certain recognized duty placed upon those in a common calling prior to the action of assumpsit. Persons who suffered a stranger or one not engaged in a calling to come in contact with his person or property had no remedy for any resulting injury, for he was not deceived or induced by any representation of skill to part with his goods, etc. The origin of the duty to serve should not be confused with that to use care, which, it is believed, is entirely different.

Professor Burdick seems to take the view that the early test applied to a "public" calling was a "holding out" to serve, which had its origin in the action of assumpsit. He says: ${ }^{12}$

"Originally when an individual voluntarily entered into dealings with another and damages ensued, through the latter's fault, there was, in the conception of the early lawyers, no tort-it was only when an assumpsit and a breach thereof were pleaded, that an action on the case could at first be maintained under such circumstances. It would seem that the origin and basis of the liability of the person engaged in a common calling for failure to serve, or for lack of care in the performance of the service, is to be found in the early developed branch of the action on the case. It was because a person held himself out to serve the public generally, making that his business, and in doing so assumed to serve all members of the public who should apply, and to serve them with care, that he was liable in an action on the case for refusal to serve or for lack of care in the performance of the service, by which refusal or lack of care he had committed a breach of his assumpsit. . . . The fact that one was a common carrier, common innkeeper, common farrier, or common tailor was of itself a general assumpsit to serve carefully in carrying, shoeing, tailoring or giving shelter, and the allegation in such actions that the person charged was a common carrier or common innkeeper, etc., involved of necessity in the word 'common' the implied allegation of an assumpsit to serve properly."

${ }^{11}$ Y. B. 9 H. vI, f. 53, pl. 37 (r430) ; Keilw. 9r, pl. 16 (r506) ; Roswell v. Vaughan, Cro. Jac. Ig6 (1607); Burnby v. Bollet, I6 M. \& W. 644, 654 (I847). ${ }^{12}$ II CoL. L. Rev. 5 I4 (IgII). 
As noted, the statement of Professor Burdick starts with the major premise that an assumpsit was necessary; ordinarily it was expressed, but might be implied from the word "common." If we ask why an assumpsit was a necessary allegation, we will arrive at the very foundation of liability in such cases. The answer is that the liability, at the time, was based upon the deceit which the person engaged in the common calling practiced upon the plaintiff, when he induced the plaintiff to allow him to come into contact with the plaintiff's goods or person, by the representation that he was skilled in his trade. ${ }^{13}$ If the plaintiff permitted any other person, not in a common calling, to do the act, and an injury resulted, he had no action. This doctrine later was extended to cases when one was not engaged in a common calling but made an express promise to use care. ${ }^{14}$ The development seems to me to be exactly reversed to that expressed by Professor Burdick. There can be no doubt that the courts a few hundred years later became confused as to the meaning or purpose of the allegation of assumpsit in the action, as I shall attempt to show later. ${ }^{15}$ They seemed to believe that the assuming (promise) or holding out, was the basis of the action when, in reality, it was merely a means of showing the deceit practised upon the plaintiff. ${ }^{16}$

Special assumpsit, it seems, had its origin in two sources. The first was the action of deceit on the case. ${ }^{17}$ The gist of the action as mentioned above was the deceit in the breaking of the promise on the faith of which plaintiff had been injured. It was

${ }^{23}$ The holding out was merely one method of showing deceit and might be shown in other ways. Y. B. 46 Ed. III, f. I9, pl. I9 (1372).

14 "So far as we can see, the common law refused to recognize negligence, i. $e$. omission of a positive duty, as the grounds of legal liability; except where the defendant had expressly taken upon himself such duty, or where (as in the case of a surgeon, common carrier, innkeeper, etc.) his profession or calling was deemed to be a "holding out' to that effect." Jenks, Negligence and Deceit in the Law of Torts, 26 LAW Q. REv. I59, I62 (I9I0).

${ }^{15}$ See 3 Holdsworth, Hist. of ENG. Law (3d Ed. 1923) 432. "It is true that in some of these cases (common callings) there would be no liability to compensate for damages caused if there had not been an undertaking; but it was not the breach of the undertaking which was the ground of the action. The ground of the action was the damage caused by the wrongful act (i.e. deceit). . . . It did not make the undertaking the grounds of the action." (1430).

${ }^{16}$ Fitz. Ab., Monst. De Faits, pl. 160 (1383) ; Y. B. 9 H. vr, f. 53, pl. 37

${ }^{27}$ Ames, op. cit. supra note I at 273. 
immaterial whether the promisee or a third person was to get the benefit of the promise. ${ }^{18}$

The second source was a development from certain other actions on the case in which an undertaking, (that is, an actual starting of the tásk) was alleged. The first cases in assumpsit were cases of common callings, as Ames points out. ${ }^{19}$ Yet this allegation of an undertaking in the first instances was not an indispensable part of the declaration, but merely incidental to showing a wrong done (such as deceit). ${ }^{20}$ Before long the courts began to conceive of the action as really being based upon the undertaking, since this allegation was found in all of the first cases. $^{21}$ "The taking of molley beforehand by the promisor" 22 was sufficietit tuidiertaking to ground an action. On this theory a breach of parol promise was just as actionable as a breach of an undertaking in a common calling. The wrong committed in both instances were of the same character. There was deceit in both cases. Professor Salmond says: ${ }^{23}$

"Trespass was-applicable only to cases of damages to a person or property of the plaintiff. But deceit included all cases in which plaintiff had suffered injury by acting in reliance ori defendant's promise."

${ }^{18}$ Defendant held for deceit, when plaintiff on strength of his promise sold goods to a third person. Y. B. I3, H. vIII, f. II, pl. 3 (I52I).

19 Supra note 6.

$\infty$ Y. B. 46 Ed. III, f. 19, pl. I9 (1372).

${ }^{21}$ Street says, "From the time when the action on the case first came into prominence, the pleader often found it necessary or proper to state, among other things, that the wrong complained of was done by the defendant while engaged in performing and undertaking an agreement. But this statement merely served to show that the injury complained of was done under such circumstances as excused the plaintiff from suing in trespass and from alleging that the wrong was done with force and arms. Negligent injury to property which had lawfully come into the defendant's care was the gist of the action, and the breach of the promise was merely incidental and collateral to the true ground of liability. In such cases the plaintiff generally alleged that the defendant undertook (enprise) (Y. B. II H. IV, f. 33, pl. 60 (I409)) or assumed (assuma sur luy) (Y. B. I9 H. vr, f. 49, pl. 5 (I440)) to do a particular act. Liability was not derived from the promise, and where the fact that the defendant did enter upon the enterprise sufficiently appedred on the facts of the case, no allegation of assumpsit, was as a matter of law, necessary (Y. B. $46 \mathrm{Ed}$. III, f. 19, pl. I9 (1372) ). As was natural, it came to pass in time that in cases where an assumpsit or undertaking on the part of the defendant was alleged, the cause of action was occasionally viewed as being in some way based on the promise. (Y. B. 48 Ed. III, f. 6, pl. II (I374) )." 3 STREet's Foundations of LEGal LIABILITY (Ig06) I73.

${ }^{22}$ Fitz. NAT. BREv. 94a; Keilw. 77, pl. 25 (1505).

${ }^{23}$ ESSAY IN JURISPRUDENCE 208. 
From what has been said by writers upon the subject, the duty to use care seems to have had its origin in tort rather than contract. It applied to all businesses alike, and still does today; no distinction being made between "public" and "private" callings, as to the duty to use care. Hence the duty to use care has no significance in the determination of those callings upon which are placed peculiar duties and those upon which no unusual duties are placed. The duty to serve all who apply is the real criterion, the writer believes, by which such businesses are to be determined.

\section{II.}

The Duty to Serve.

Thus far it has been shown that those engaged in a calling were liable at common law for their negligent acts while engaged in their trade. But if an individual chose to employ a stranger not professing a trade to do the act, he had no remedy if an injury occurred. This duty seems to have been applied to all callings alike. Fitzherbert said as late as $\mathrm{I}_{5} \mathrm{I}_{4},{ }^{24}$ "It is the duty of every artificer to exercise. his art rightly and truly as he ought." Today, also, the duty to use care is placed alike upon all businesses or callings. No distinction seems, in the early days, to have been made between "public" and "private" callings, so far as the duty to use care was concerned. The distinction made was between those engaged in a trade or "common" occupation, and those unskilled in any trade. If one chose to allow one of the latter class to come into contact with his person or goods, he assumed the risk of injury, without any remedy for damages. This fact, it is believed, is the occasion for the use of the word "common" in connection with the occupation of the defendant. The writer thinks there is no basis for any classification of business into public or private. There is neither logic nor practicability in such an arrangement, nor is there any reason historically for such a division. The word "common" meant simply "business." 25 That is, one engaged in work as a trade in which he

${ }^{24}$ Fitz. Nat. Brev. 94d.

${ }^{25}$ In 1367 a perfect illustration is given of the use of the word "common" in the order for porters and creelmen, "who exercise that craft commonly." Beverly Town Doc. 2 I. 
made his living. It seems then, the words "common carrier" meant one in the business of carrying as a trade, as distinguished from one who did it as a casual act or by special agreement. ${ }^{26}$ The word is used in this sense and not in the present sense of "public" in all the early instances, as: common merchant, common marchal, common schoolmaster, common surgeon. ${ }^{2 t} \mathrm{Sir}$ William Jones, ${ }^{28}$ Blackstone, ${ }^{28}$ Justice Story, ${ }^{30}$ and Chancellor

* As late as 1710 it was said in Gisbourn v. Hurst, I Salk. 249, that "goods delivered to any person exercising a public trade or employment, to be carried, wrought or managed in the way of trade or employ, are for the time under legal protection, and privilege from distress for rent."

IT Y. B. 7 H. IV, f. 44 , pl. If (I405); Y. B. Ig H. vr, f. 49, pl. 5 (I440); Y. B. 9 Ed. rv. f. 32, pi. 4 "( $(469)$; Y. B. Ig H. VI, f. 49. pl. 5 (1440).

${ }^{28}$ Sir William Jones says, "It is indisputably clear, that an action lies in both cases for reparation or damages whenever the work was undertaken for a reward either actually paid or expressly stipulated, or in the case of the common trader, strongly implied, of which Blackstone gives the following instance: 'If a builder promises, undertakes or assumes to Caius that he will build and cover his house within a time limited, and fails to do it, Caius has an action on the case against the builder for this breach of his express promise, and shall recover a pecuniary satisfaction for the injury sustained by such delay: ( $3 \mathrm{BL}$. CoM.

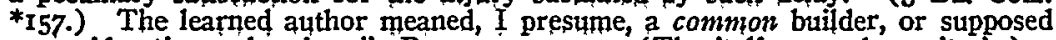
a consideration to be given." BAmMrenrs 100. (The italics are the writer's.)

" Blackstone says, "The last class of contracts, implied by reason and construction of law, arise upon this supposition, that every one who undertakes any office, employment, trust, or duty, contracts with those who employ or intrust him to perform it with integrity, diligence, and skill. . . . There is also in law always an implied contract with a common innkeeper to secure his guest's goods in his inn; with a common carrier, or bargemaster, to be answerable for the goods he carries, with a common farrier, that he shoes a horse well, without laming him; with a common tailor, or other workman, that he perform his business in a workmanlike manner; in which if they fail, an action on the case lies to recover damages for such breach of their original undertaking (II Rep. 54, I Saund. 312a). But if I employ a person to transact any of these concerns, whose common profession and business it is not, the law implies no such general undertaking; but in order to charge him with damages, a special agreement is required. Also, if an innkeeper or other victualler, hangs out a sign and opens his house for travelers, it is an implied engagement to entertain all persons who travel that way; and upon his universal assumpsit and action upon the case will lie against him for damages if he without good reason refuses to admit a traveler. (I Vent 333.)" 3 BL. Cosr. * I65.

${ }^{30}$ Justice Story says, "Who are deemed common carriers? It is not (as we have seen) every person who undertakes to carry goods for hire, that is deemed a common carrier. A private person may contract with another for the carriage of his goods and incur no responsibility beyond that of any ordinary bailee for hire, that is to say, the responsibility of ordinary diligence. (Bac. Abr., Carriers, A; Robinson v. Dunmore, 2 Bos. \& Pul. 4I7 (I8or); Hodgson v. Fullarton, 4 Taunt 787 (I8I3) ). To bring a person within the description of a common carrier he must exercise it as a public employment; he must undertake to carry goods for persons generally; and he must hold himself out as ready to engage in the transportation of goods for hire as a business, not as a casual occupation, pro hac vice (Gisbourne v. Hurst, I Salk. 249 (I710); Sutterlee v. Groat, I Wend. 273 (N. Y. I828) ; I Bell Com. (5th ed.) 467). A common carrier has, therefore, been defined to be one who undertakes for hire or reward 
Kent ${ }^{31}$ explain the law on the subject by this theory of the meaning of the word "common." 32

A fundamental difficulty lies in the conception that business is of two classes, public and private, and that the latter is subject to no duties to individuals without agreement, or control by the state. Carrying on a business is not a casual act, but a habitual and common practice of rendering service for compensation. "Common" as used in "common carrier" is generally assumed to mean "public," when in reality the original use of the adjective was merely to distinguish those who carried as a trade and those who carried as occasional acts. Businesses, it is true, had certain peculiar duties placed upon them, such as the duty to serve all who applied; but this was because of the peculiar economic conditions of the time, it is believed. The reason for these duties being placed upon a business, was not because it was "public" but because it was more important to the public at the particular time. ${ }^{33}$

The legal content of the phrase "public calling" may now be too firmly woven into the legal fabric to hope for much change, but its original significance should not be lost sight of. The classification seems not to have been based upon any inherent characteristic of the business itself, but the division was made upon a factor outside the business which varied as centuries went by. All trades in time of distress or economic paralysis were affected with a very high degree of public interest. The duty to

to transport the goods of such as chose to employ him from place to place. (Dwight v. Brewster, I Pick. 50, 53 (Mass. I822); Gisbourne v. Hurst, I Salk. 249, 250 (I710).)" Barlments ( 9 th ed. I878) 464, $\$ 489$.

${ }^{31}$ Chancellor Kent says, "Common carriers undertake, generally, and not as a casual occupation and for all people indifferently, to convey goods, and deliver them at a place appointed, for hire as a business." 2 KENT CoM. * *599.

${ }^{32} \mathrm{Mr}$. Adler takes the view that "common" meant "business," but contends that the law of callings applied to all businesses without reference to monopolistic conditions, originally. But it is to be noted that the number is comparatively few up to the year I 400 ; not more than has already been mentioned. He makes his largest list of businesses in the year sixteen hundred and following. As shown above, the law of public callings originated between 1300 and 1400 because of the monopolistic and oppressive conditions of business and trade at the time of the Black Death. Hence the conditions and number in business two hundred years later has no relation to conditions in 1400 or prior thereto. See 28 HARv. L. REv. I 49 .

${ }^{33} 3$ HoldSWORTH, op. cit. supra note I5 at 385-6. 
serve, and not the duty to use care, in such times, was the distinguishing feature of the public interest of the trade or business. Those upon whom the duty to serve is placed may vary with economic conditions, but not those upon whom the duty to use care is placed. 34

What were the ecenomic conditions, then, which, in the Fourteenth Century brought most, if not all, businesses within a class which had placed upon them by law, without special agreement, the duty to serve all who applied? An investigation of the trade conditions between 1300 and the rise of the action of assumpsit will throw much light on the subject.

The first case we have on record, of those in a common calling, is that of the ferryman of $1348 .^{35}$ In that same year the Black Death broke opt in Fngland and swept the entire country. The death rate was estimated from nine-tenths to one-fifth of the entire population. ${ }^{36}$ Holdsworth places it at one-half of the population. ${ }^{37}$ Laborers and tradesmen of all kinds found themselyes in a position to exact any price they pleased. The Statutes of Labourers were passed to deal with this situation ${ }^{38}$ the first in I349. The principles found throughout all of these statutes were: all must work who are able; at a reasonable rate; and none could refuse to practise his calling to whomever applied. In 1363 it was enacted that handicraftsmen should pursue one trade only. ${ }^{39}$ This was to prevent them from changing from

ss The writer is quite unable to agree with Professor Burdick's statement when he says, "But in fact it seems to me that the position of one who is engaged in a common calling and refuses to serve an applicant is quite distinguishable from the carpenter who promises to build a house and does not do so. The former has in fact entered upon the undertaking of a common calling while the carpenter has entered upon no undertaking, and when the former refuses to serve he is not really refusing to enter upon an undertaking as the carpenter is but is refusing to perform the public undertaking already entered upon." II COL L. REV. at 517,518 (I9II). It is submitted, that if the carpenter is a consmon carpenter (one who makes such his trade) he holds out to the public to as great an extent as any other business now classed under the phrase "public calling."

${ }^{35}$ Y. B. 22 Ass. 94, pl. 4 I (1348).

*32 Col. Univ. Stud. in Hist. Econ. and Pub. Law i (1908).

${ }^{37} 2$ HOLDSWORTH 460.

${ }^{23}$ (1349) 23 Ed. III; (135I) $25 \mathrm{Ed}$ III; (1357) 3I Ed. III st. I, c. 6; (1359) 33. Ed. III C. 9-II; (1363) 37 Ed. III c. 5-14; (1368) 42 Ed. III c. 6; (1378) 2 Rich. II c. 8; (1383) 7 Rich. II c. 5 ; (1388) I2 Rich. II c. 3-5, 7, 9, 13.

(1363) 37 Ed. III c. 6 . 
one trade to another, where the restrictions were not so burdensome. In 1388 , because of the shortage of agricultural laborers, it was enacted that those who served until the age of twelve should not be apprenticed to any other trade. Statutes were directed against forestalling, regrating, conspiracies to raise prices, guild ordinances to secure monopolies of trade, etc. ${ }^{40}$ Statutes were passed regulating the price and penalizing a refusal to serve in all trades. ${ }^{41}$ All problems they sought to solve by legislation. ${ }^{42}$ The fact that there was so much criminal legislation at this time probably accounts for the fact that there were very few civil cases on the subject, especially for refusal to serve, while indictments for excessive prices were very common. ${ }^{43}$

${ }^{40}$ (I436) I5 H. vI c. 6.

"Victuallers, (1357) 3I Ed. IIr c. Io; Fishermen, (136r) 35 Ed. III c. I; Tailors, etc., (I454) 33 H. vI c. 5 ; Chandlers, (I432) II H. vI c. I2; Shoemakers, (1464) 4 Ed. Iv. c. 7.

"Holdsworth says, "We do not find, it is true, general statements that certain specific acts, such as combinations to raise wages or otherwise to restrict trade are wrongful (at common law), 'But the clearer a thing is,' it was once said by James, L. J., 'the more difficult it is to find any express authority or any dictum exactly to the point ([1875] Io Ch. App. 526) and to the medixval mind the view that the law could punish any departure from the ordinary conditions and modes of trading would have seemed self-evident. (Erle, Trade Unions 5-II, 25.) . . . We have seen that a judge in Henry V's reign seemed to think that to make a contract in restraint of trade was almost a crime. (Y. B. 2 H. I, Pasch, pl. 26 (14I4)) and whether a departure from the ordinary modes and conditions of trading should be treated as a crime or tort, the mediæval lawyer or legislator would probably not have stopped to enquire." 2 HOLDSWORTH 470.

${ }^{43}$ One such King's Bench indictment reads :

"Indictment for excessive prices charged by Craftsmen.

"Further they (the jurors) say that dyers, drapers and tanners are dwelling in the town of Ware, where they were not wont to be, but within the borough of Hertford, to the grave damage of the Lord the King, and the Lady Queen Isabel, Lady of the same town of Hertford aforesaid, and against the liberty of the aforesaid Queen, and that the same dyers and tanners use their craft in too excessive wise, to wit, the aforesaid dyers take for a cloth sometimes half a mark, sometimes 4 od. and sometimes more, where they were wont to take for a cloth $6 \mathrm{~d}$. only, and the aforesaid tanners buy oxhides and divers other hides at a low price and refuse to sell them unless they gain on the sale fourfold, to the greatest oppression and damage of the whole people." K. B. ANCIENT INDICrMENTS (1354) 38, m. 22d, reprinted in Bland, Brown \& TAwney, ENg. EcoN. Hist. Select Doc. I69.

A writ to enforce Payment of Excess of Wages to the Collectors of a Subsidy :

"We command you to compel all and singular artificers, servants and workmen, as well as women, of whatsoever condition they be, convicted or hereafter to be convicted before you of such excessive salaries, liveries, 
Economic conditions of the time, as manifested by contemporaneous legal records, show the monopolistic state of trades and businesses and statements of students and writers seem to be unanimous upon this point..4 Edward IIf was exceedingly enterprising in his commercial policy as shown by the statutes of the day. Monopoly crafts and special franchises were the only rules of business, and regulation of prices by statute the usual condition. At this time, also, the craft guilds aided materially in setting up monopolistic conditions. Trades were limited, craftsmen were scarce and formed into monopolistic organizations. ${ }^{45}$ Wherever manopolistic tendencies appeared, the business, irrespective of kind, was limited and regulated to any degree necessary for the puplic gaod. This seems to have peen the early test of a

hires, or stipends, whatsoever received by them . . . as well by imprisonment of their bodies as in other lawful manner. . . to pay to you without delay that which they have so received in excess. the King at Westminstert, I2 Junie." (1350) Close Roli, 24 Ed. III p. I, m. 6d, reprinted in BLAND, BRowN \& TAWNEY, supra at I7o. For a list of fines assessed, etç., see Exch. K. R. Estreats, II, 2 (I35I); Subsidy Roll IOO7, 4I (1352), reprinted in BLAND, BROWN \& TAWNEY, supra at I69, I7I.

"Abrams says (ENGlish Life and Manners of the Mimdle Ages 81): "Merchants in turn became exclusive and endeavored to obtain monopolies of sale of their commodities and consequently it was necessary to check their aggression by law.". . . Evidence of the struggle against monopolies may also be seen in an attempt to obtain the right to sell herring anywhere in Great Yarmouth at the time of the herring fair, but its failure as Miss Law points out was chronicled by the Statute of Herring (1357)."

I Polrock and Maitland, History of English Law 644: "In London definite civic legislation [of trade] begins at an early period. In 1189 FitzAlwyne's Assize was issued. It has been well called the earliest English 'Building Act' (Munim. Gildh. pp. xxx. 3I9); it contains some stringent provisions as to the houses that men may erect. A somewhat similar ordinance was issued in 1212 after a great fire, and it did not scruple to fix the rate of wages for masons, carpenters, tilers and the like (Munim. Gildh. ii., 86). Thenceforward ambitious attempts were made to regulate the price of commodities and the business of various crafts."

SALZMANN, HENRY II, 225: "With the growth of trade other unauthorized gilds sprang up, and in II80 no fewer than nineteen such 'adulterine' gilds were reported in London alone." . . .

${ }^{45} 2$ HoznsworTH 463 , "That wages and prices should be fixed by free competition, they would have thought a monstrous absurdity. Can we in the twentieth century who live in an atmosphere of free competition tempered by strikes, lockouts, and rings, say, as decisively as economists of the middle nineteenth century, that the views held by the legislature in the fourteenth century were unreasonable? That its views on these matters were in fact reasonable, both for the fourteenth century and long after, can be seen from the fact that both the status of the labourer as defined by these statutes and decisions, and many of the other provisions of these statutes were adopted by framers of the statute of $1562-1563$ ( 5 Eliz. c. 4) which fixed the main principles of the law of employer and workman for more than a century and a half." 
"public" calling. ${ }^{46}$ The duty to serve was the essence of the regulations of the time.

The case of 1450 is possibly the earliest case for refusal to serve. ${ }^{47}$ In that case it was agreed by the court:

"that where a smith declines to shoe my horse, or an innkeeper refuses to give me entertainment at his inn, I shall have an action on the case, notwithstanding no act is done; for it does not sound in covenant. . . . Note, that in this case a man shall have no action against innkeeper, but shall make complaint to the ruler, by $5 \mathrm{Ed}$. IV 2, contra, I4 $\mathrm{H}$. VII 22."

This note seems to indicate that there was some confusion as to where the liability arose, whether by common law or by statute. There seems to have been a liability at common law without a statute, for we have also the court saying about this time ${ }^{48}$ that if a smith refuses to shoe my horse or if he pricks him, an action on the case lies against him. Not many such cases were likely to arise during the thirteenth, fourteenth and fifteenth centuries, because the duty to serve all was so fully covered by criminal statutes of the times. It is more likely the plaintiff would prefer to pay whatever price was asked in order to get the service, because of the monopoly arising from immediate needs, and then have the person indicted, as records show was a common practice. ${ }^{49}$

In $\mathrm{r}^{\mathrm{I} 8}$ in The Doctor and the Student it is said:50

\footnotetext{
${ }^{40}$ The conclusions presented here it seems accord with those of Professor Wyman, although we traveled along different lines in reaching them. He says, "Those in a public calling have always been under the extraordinary duty to serve all comers, while those in private business may always refuse to sell if they please. So great a distinction as this constitutes a difference in kind of legal control rather than merely one of degree. The causes of this division are, of course, rather economic than strictly legal; and the relative importance of these two classes at any given time, therefore, depends ultimately upon the industrial conditions which prevail at that period. Thus in the England which we see through the medium of our earliest law reports the medieval system of established monopolies called for legal requirements of indiscriminate service from those engaged in almost all employments. There followed in succeeding centuries an expansion of trade which gradually did away with the necessity for coercive law." I Wyman, Public Service Corporations (IgiI) 2.

${ }^{47}$ Keilw. 50, pl. 4 (1450).

${ }^{48}$ Keilw. 50; Roll. Abr. 91 ; Saund. 312.

-Supra notes $4 \mathrm{I}, 42,43$.

${ }^{30}$ Supra note 4 .
} 
"And if he would percase refuse to carry it unless promise were made unto him that he shall not be charged for no misdemeanor that should be in him, the promise were void; for it were against reason."

If was also said :51

"If an innkeeper refuses a guest on pretense that his house is full of guests, if this be false, action on the case lies."

But then it was stated :52

"An action cannot be maintained against a carpenter simply as such and without any express consideration for an injury sustained in consequence of his not entering upon a piece of work which he had engaged to perform." ${ }^{53}$

Very early we see that the duty to serve on request became inyolved in the development of assumpsit and actions for breach of parol promises. Yet the refusal to hold a carpenter in this case and the succeeding ones may! be explained on two grounds. First, that this might not have been a "common" carpenter, the view taken by Sir William Jones.. ${ }^{54}$ Second, economic conditions had changed sufficiently to warrant a change in those upon whom the duty to serve was placed. This, I believe, is the true explanation of the case. If such a case had occurred one hundred years earlier, at the time when such duty was imposed upon all callings, the carpenter's case would unquestionably have been placed in line with the smith, the tailor, the surgeon, etc.

At the time when the carpenter's case came up, the law of assumpsit was stated by Newton (I436) $:^{55}$

"If a carpenter makes a covenant with me to make a house good and strong and of certain form and he makes me a house which is weak and bad and of another form, I shall have an action of trespass on my case. So if a smith

1 I Roll Abr. 3.

I I Bacon Abr. *93.

Citing Elsee v. Gatward, 5 T. R. I43 (1793), and see Y. B. 2 H. Iv, f. 3, pl. 9 (I400); iI H. Iv, f. 33, pl. 60 (I409).

JONES, BATLMENTS 100.

${ }^{w}$ Y. B. I4 H. vI, f. 18, pl. 58 (1436). 
makes a covenant with me to shoe my horse well and properly, and he shoes him and lames him, I shall have a good action. So if a doctor takes upon himself to cure me of my disease and he gives me medicine, but does not cure me, I shall have an action on my case. So if a man makes a covenant with me to plough my land in seasonable time and he ploughs in a time which is not seasonable I shall have my action on my case. And the cause is in all these cases that there is an undertaking, and a matter in fact beyond the matter which sound merely in covenant."

It is to be noted that the cases of the smith and surgeon were included with the carpenter. There can be no doubt about the liability of all such trades in the earlier law, but times were changing and we begin to see some doubts arising as to the liability for refusal to serve.

In the same year ( 1436 ) that Newton made the statement above, we see still some expressions of the earlier law coming up. Paston and Juyn, JJ., say: ${ }^{56}$

"It is said that if a carpenter takes upon himself to make me a house and he does not do so, I shall have no action upon my case: Sir, I say that I shall. And sir, if in your hostelry a smith makes a covenant (promise?) with me to shoe my horse, and he does not do so, and I move on, and my horse has no shoes, and is injured for want of shoes, I shall have my action on my case. And if you who are Serjeant at law take upon yourself to plead my plea and do not do it or do it in another manner to that which I have directed so that I lose, I shall have an action on my case . . ." Juyn, J.: "Agreed, and as Paston has said if the smith does not shoe my horse I shall have an action just as much as if he shod him and lamed him; for all that is dependent upon the agreement and merely accessory to it; and as I have an action upon that which is accessory, I shall have an action on the principal." Paston: "that is well said." 57

The law as thus understood was stated for the last time.

${ }^{s s}$ Ibid.

${ }^{\text {BT }}$ Professor Burdick offers quite an ingenious explanation of the cases: "But in fact it seems to me that the position of one who is engaged in a common calling and refuses to serve an applicant is quite distinguishable from that of the carpenter who promises to build a house and does not do so. The former has in fact entered upon a general undertaking of a common calling, while the 
Business and economic conditions were changing in England. Trade and commerce were increasing. Three or four generations had passed since the Black Death. Valid reasons existed for not extending the duty to serve and for dropping many businesses already in this class, such as the smith, surgeon, or carpenter.

The case of the carpenter can also be explained on the ground that he was not a "common" carpenter. On this, Sir William Jones says: ${ }^{58}$

"In regard to the distinction before mentioned between the nonfeasance and the misfeasance of a workman, it is indispitably clear, that an action lies in both cases for a reparation in damages, whenever the work was undertaken for a reward, either actually paid, expressly stipulated, or, in the case of a common trader, strongly implied; of which Blackstone gives the following instance: 'If a builder promises, undertakes or asstimes to Caius that he will build and cover his house within a time limited, and fails to do it, Caius has an action on the case against the builder for his breach of his express promise, and shall recover a pecuniary satisfaction for the injury sustained by such delay.' The learned author meant, I presume, a common builder or supposed a consideration to be given; and for this reason I forbore to cite his doctrine as in point as the subject of an action for non-performance of a mandatory." 59

But this distinction not being drawn in the case, the economic theory, which deals with fundamentals, seems the better explanation.

If what has been said here is true, the same reason exists today for the law of public callings in the cases in which it applies (and probably others) as in those cases of earlier days. What has been said, the writer thinks, bears out Professor Wyman's forecast, a few years ago, of the probability that the law

carpenter has entered upon no undertaking, and when the former refuses to serve he is not really refusing to enter upon an undertaking as a carpenter is, but is refusing to perform the public undertaking already entered upon." II CoI L. REV. 514 at 518 (I9II). It is difficult for the writer to conceive of any public undertaking in those days in the case of the tailor, smith, victualler, and not in the case of the carpenter. Shelter is as important to man as shoes for his horse, food or clothing. Also see note 33 supra for other comments upon this view.

Supra note 54 .

Italics are the writer's. 
of public callings may be invoked in cases of the monopolistic trust problems of modern times. ${ }^{60}$ Those in the class have changed and will continue to change with altered economic conditions, but the reason still exists for the class, call it monopoly, possibility of oppression, economic advantage, public emergency or what not.

The following conclusions may be drawn from what has been said:

I. The duty to use care applied to all trades and callings in the first instances.

2. The only distinction made in the imposition of this duty was between those engaged in a trade or calling as a common practice, and those who did the same acts by special agreement occasionally. In the latter case no remedy existed in early law for any injurious consequences resulting from the transaction.

3. The duty to serve has its origin at an entirely different time (i.e., Black Death) from that of the duty to use care.

4. The duty to serve, it seems, was placed upon all trades and callings during the time of the Black Death. This may account for the confusion of the word "common" with "public."

5. The cases reveal a confusion at the time as to whether there was also a common law liability for refusal to serve besides that imposed by penal statutes.

6. The duty to serve was the first distinguishing characteristic of the class of businesses known today as "public callings."

7. The classification was made, not upon some inherent characteristic of the business itself, but upon a factor outside the business which varied as times changed, as the carpenter cases reveal.

8. This factor was economic conditions, which determined those upon whom the duty to serve was placed, or in other words, the importance of the business to the public.

Washburn College Law School,

Norman F. Arterburn.

Topeka, Kansas.

if HaRv. L. REv. I56 (1904). 